Mammalian Genome, Vol. 21(9-10), pp. 427-441

\title{
Recommended Nomenclature for Five Mammalian Carboxylesterase Gene Families: Human, Mouse and Rat Genes and Proteins
}

Roger S Holmes ${ }^{1-4}$, Matthew Wright ${ }^{5}$, Stanley JF Laulederkind ${ }^{6}$, Laura A Cox ${ }^{122}$, Masakiyo Hosokawa ${ }^{7}$, Teruko Imai ${ }^{8}$, Shun Ishibashi ${ }^{9}$, Richard Lehner ${ }^{10}$, Masao Miyazaki ${ }^{11}$, Everett J Perkins ${ }^{12}$, Phillip M Potter ${ }^{13}$, Matthew Redinbo ${ }^{14}$, Jacques Robert ${ }^{15}$, Tetsuo Satoh ${ }^{16}$, Tetsuro Yamashita ${ }^{17}$, Bingfang Yan ${ }^{18}$, Tsuyoshi Yokoi ${ }^{19}$, Rudolf Zechner ${ }^{20}$ and $^{2}$ Lois Maltais ${ }^{21}$

${ }^{1}$ Department of Genetics, ${ }^{2}$ Southwest National Primate Research Center, Southwest Foundation for Biomedical Research, San Antonio, TX, USA; ${ }^{3}$ School of Biomolecular and Physical Sciences, Griffith University, Brisbane Qld Australia; ${ }^{5}$ European Bioinformatics Institute, Wellcome Trust Genome Campus, Cambridge, UK; ${ }^{6}$ Rat Genome Database, Human Molecular Genetics Center, Medical College of Wisconsin, Milwaukee, WI, USA; $\quad{ }^{7}$ Laboratory of Drug Metabolism and Biopharmaceutics, Chiba Institute of Science, Choshi, Chiba, Japan; ${ }^{8}$ Graduate School of Pharmaceutical Sciences, Kumamoto University, Kumamoto, Japan; ${ }^{9}$ Department of Medicine, Jichi Medical University, Shimotsuke, Tochigi, Japan; ${ }^{10} \mathrm{CIHR}$ Group on Molecular and Cell Biology of Lipids, University of Alberta, Edmonton, Canada; ${ }^{11} \mathrm{The}$ Institute of Glycoscience, Tokai University, Kanagawa, Japan; ${ }^{12}$ Department of Drug Disposition, Lilly Research Laboratories, Eli Lilly and Company, Indianapolis, IN USA ${ }^{13}$ Department of Molecular Pharmacology, St. Jude Children's Research Hospital, Memphis, TN USA; ${ }^{14}$ Department of Chemistry, University of North Carolina at Chapel Hill, Chapel Hill, NC, USA; ${ }^{15}$ Laboratoire de Pharmacologie, Institut Bergonié, Bordeaux Cedex, France; ${ }^{16}$ Graduate School of Pharmaceutical Sciences, Chiba University, Japan;

${ }^{17}$ Department of Agro-bioscience, Iwate University, Morioka Japan; ${ }^{18}$ Department of Biomedical and Pharmaceutical Sciences, University of Rhode Island, Kingston, RI USA; ${ }^{19}$ Division of Pharmaceutical Sciences, Graduate School of Medical Science, Kanazawa University, Kanazawa, Japan; ${ }^{20}$ Institute of Molecular Biosciences, University of Graz, Austria; ${ }^{21}$ The Jackson Laboratory, Bar Harbor, ME, USA;

${ }^{4}$ Corresponding Author:

Roger S Holmes, Department of Genetics, Southwest National Primate Research Center, Southwest Foundation for Biomedical Research, San Antonio, TX, USA 78227 Email: rholmes@ sfbrgenetics.org

Phone: 210-258-9687 Fax: 210-258-9600

Keywords: Human; mouse; rat; carboxylesterases; gene nomenclature; enzymes.

Running Head: Human, mouse and rat carboxylesterase gene nomenclature 


\title{
Recommended Nomenclature for Five Mammalian Carboxylesterase Gene Families: Human, Mouse and Rat Genes and Proteins
}

\author{
Abstract \\ Mammalian carboxylesterase (CES or Ces) genes encode enzymes that participate in xenobiotic, drug and lipid metabolism in the body and are members of at least 5 gene \\ families. Tandem duplications have added more genes for some families, particularly for mouse and rat genomes, which has caused confusion in naming rodent Ces genes. A \\ new nomenclature system for human, mouse and rat carboxylesterase genes is described which identifies homolog gene families and allocates a unique name for each gene. \\ The guidelines of human, mouse and rat gene nomenclature committees were followed and "CES" (human) or "Ces" (mouse and rat) root symbols were used followed by the \\ family number (eg human CES1). Where multiple genes were identified for a family or where a clash occurred with an existing gene name, a letter was added (eg. human \\ CES4A; mouse and rat Cesla) which reflected gene relatedness among rodent species (eg. mouse and rat Cesla). Pseudogenes were named by adding " $P$ " and a number to \\ the human gene name (eg. human CESIP1) or by using a new letter followed by ps for mouse and rat Ces pseudogenes (eg. Ces $2 d-p s$ ). Gene transcript isoforms were named \\ by adding the Genbank accession ID to the gene symbol (eg human CES1_AB119995 or mouse Ces1e_BCO19208).This nomenclature improves our understanding of human, \\ mouse and rat $C E S / C e s$ gene families and facilitates research into the structure, function and evolution of these gene families. It also serves as a model for naming $C E S$ genes \\ from other mammalian species.
}




\section{INTRODUCTION}

Five families of mammalian carboxylesterases (CES; E.C.3.1.1.1) have been described including CES1, the major liver enzyme (Munger et al., 1991; Shibata et al. 1993; Ghosh 2000; Holmes et al., 2009a); CES2, the major intestinal enzyme (Langmann et al. 1997; Schewer et al. 1997; Holmes et al., 2009a); CES3, expressed in brain, liver and colon (Sanghani et al. 2004; Holmes et al., 2010); CES5 (also called CES7 or cauxin), a major urinary protein of the domestic cat also present in human tissues (Miyazaki et al. 2003; 2006; Holmes et al., 2008a; Zhang et al., 2009); and CES6, a predicted CES-like enzyme in brain (Clark et al., 2003; Holmes et al., 2009a) (reviewed by Williams et al., 2010). These enzymes catalyse hydrolytic and transesterification reactions with xenobiotics, anticancer pro-drugs, and narcotics (Satoh \& Hosokawa 1998;

2006; Satoh et al. 2002; Ohtsuka et al. 2003; Redinbo \& Potter 2005), the conversion of lung alveolar surfactant (Ruppert et al. 2006) and several lipid metabolic reactions 
(Tsujita \& Okuda 1993; Becker et al. 1994; Ghosh 2000; Hosokawa et al. 2007; Diczfalusy et al. 2001), and may assist with the assembly of low density lipoprotein particles in liver (Wang et al. 2007).

Structures for human and animal CES genes have been reported, including rodent CES1 and CES2 'like' genes (Ghosh et al. 1995; Dolinsky et al. 2001; Hosokawa et al. 2007) and human CES1 and CES2 genes (Becker et al. 1994; Langmann et al. 1997; Ghosh 2000; Marsh et al. 2004). Predicted gene structures have been also described for the human CES3, CES5 and CES6 genes, which are localized with CES1 and CES2 in two contiguous CES gene clusters on human chromosome 16 (Holmes et al. 2008 a; 2009a,b; 2010). In addition, a CES1-like pseudogene (currently designated as CES4) is located with the CES1-CES5 gene cluster (Yan et al., 1999). Mammalian CES genes usually contain 12 to 14 exons of DNA encoding CES enzyme sequences which may be shuffled during mRNA synthesis, generating several CES transcripts and enzymes encoded by each of the CES genes (see Thierry-Mieg and Thierry-Mieg, 2006). There are significant sequence similarities for the five CES families, especially for key regions previously identified for human liver CES1 (Bencharit et al. 2003; 2006; Fleming et al. 2005). Three-dimensional structural analyses of human CES1 have identified three major ligand binding sites, including the broad specificity active site, the 'side door' and 'Z-site', where substrates, fatty acids and cholesterol analogues respectively, are bound; and an active site 'gate', which may facilitate product release following catalysis (Bencharit et al. 2003; 2006; Fleming et al. 2005).

Because of the confusion associated with the current nomenclature for mammalian CES genes, particularly for mouse and rat CES genes where significant gene duplication events have generated a large number of Ces1-like and Ces2-like genes (see Berning et al., 1985; Ghosh et al., 1995; Satoh \& Hosokawa, 1995; Dolinsky et al., 2001; Hosokawa et al., 2007), this paper proposes a new nomenclature system which enables easy identification of $C E S$ family members for this enzyme. The nomenclature follows the guidelines of the human, mouse and rat gene nomenclature committees and allocates a new name for each human $(C E S)$ or mouse and rat (Ces) gene. It also names and identifies the gene family origin for identified $C E S$ pseudogenes and provides a system for naming transcript isoforms derived from each of the $C E S$ genes. The nomenclature has the flexibility to accommodate new human, mouse and rat $C E S$ genes and will assist further research into the structure, function and evolution of these gene families as well as serving as a model for naming CES genes from other mammalian species.

\section{GUIDING PRINCIPLES FOR THE NEW CES NOMENCLATURE}


The new nomenclature system for human, mouse and rat CES genes and enzymes is based on the identification of homolog gene families and a subsequent allocation of a unique gene name for each of the genes observed from genome data bases or reported from previous studies. It follows the guidelines of the human, mouse and rat gene nomenclature committees and recommends the naming of homolog $C E S$ or $C e s$ genes among species. The italicized root symbol "CES" for human and "Ces" for mouse and rat genes were used, followed by an number describing the gene family (examples include CES 1 for human CES family 1 or Ces 1 for mouse and rat Ces family 1 genes) (Tables 1-3). For mammalian genomes where multiple genes were identified or where a gene required a name which clashed with an existing name, a capital letter (for human genes) (eg. CES4A) or a lower case letter (for mouse and rat genes) (eg. Cesla, Ces $1 b$ for multiple mouse Ces 1 -like genes) was added after the number. The letter used for multiple genes reflected the relatedness of the genes across species (eg. reflecting higher degrees of identity for mouse and rat $C e s I a$ genes). When a human $C E S$ pseudogene was identified, a capital "P" and a number were added to the gene name (eg. CESIPI), whereas for mouse and rat Ces pseudogenes, a unique lower case letter was used followed by “-ps" (eg. Ces2d-ps). Transcript isoforms of human (CES), mouse and rat (Ces) gene transcripts were designated by following the gene name with the Genbank transcript ID, such as human CES1_AB119997 and CES1_AB187225 which differs from the current nomenclature used for human CES1 isoforms (CES1A1 and CES1A2, respectively) (see Table 1).

\section{HUMAN CES GENES}

Table 1 summarizes the locations and exonic structures for human CES genes based upon previous reports for human CES1 and CES2 (Becker et al. 1994; Langmann et al. 1997; Ghosh 2000; Marsh et al. 2004) and predictions for human CES3 (Holmes et al., 2010), CES4A (Holmes et al., 2009a) and CES5A (Holmes et al., 2008a) (the February 2009 human reference sequence (GRCh37) was used in this study) (Rhead et al., 2010). Human CES1P1 (a CES1-like pseudogene), CES1 and CES5A were located in a cluster (cluster 1) on chromosome 16 while $C E S 2, C E S 3$ and $C E S 4 A$ were in a separate cluster (cluster 2) on the same chromosome. Cluster 1 CES genes (CES1 and CES5A) were transcribed on the negative strand, whereas cluster 2 genes (CES2, CES3 and CES4A) were transcribed on the positive strand. Figure 1 summarizes the predicted exonic start sites for human $C E S$ genes, with CES1 and CES4A containing 14 exons; CES3 and CES5A 13 exons; and CES2 with 12 exons. These exon start sites were in identical or similar positions to those reported for CESI (Ghosh, 2000; March et al., 2004). Figure 2 shows the comparative structures for human CES reference sequences and transcripts described 
on the AceView website (http://www.ncbi.nlm.nih.gov/IEB/Research/Acembly/) (Thierry-Mieg \& Thierry-Mieg, 2006). The CES gene and transcript sequences varied in size

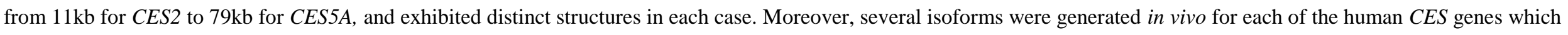
have different structures, as a result of transcriptional events including truncation of the 5' ends, differential presence or absence of exons, alternative splicing or retention of introns or overlapping exons with different boundaries. In addition, the isoforms are differentially expressed in tissues of the body and may perform distinctive metabolic roles. CES isoforms were named by using the gene name followed by the Genbank ID for the specific transcript. Recent studies of human CES1 have described at least two major isoform transcripts, designated as CES1A1 (AB119997) and CES1A2 (AB119996) (Tanimoto et al., 2007). These isoforms have been redesignated as CES1_AB119997 and CES1_AB119997, respectively (see Table 1) and encode sequences which differ by only 4 amino acid residues within the N-terminal region (exon 1) (Tanimoto et al., 2007). Distinct 5'-untranslated consensus sequences for binding transcription factors were reported which suggested differences in transcriptional regulation and functional roles in contributing to CPT-11 chemosensitivity for these isoforms (Tanimoto et al., 2007; Hosokawa et al., 2008; Yoshimura et al., 2008). Fukami and coworkers (2008) have also

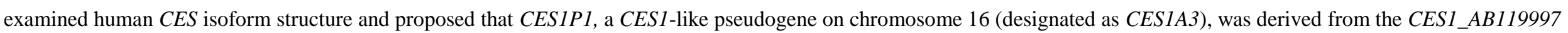
isoform.

\section{HUMAN CES AMINO ACID SEQUENCES AND STRUCTURES}

An alignment of the amino acid sequences for human CES-like protein subunits are shown in Figure 1, together with a description of several features for these enzymes. The sequences have been derived from previously reported sequences for CES1 (Munger et al., 1991; Shibata et al., 1993); CES2 (Langmann et al., 1997; Schewer et al., 1997); CES3 (Sanghani et al., 2004); CES4A (previously CES6 or CES8) (Holmes et al., 2009a); and CES5A (previously CES7) (Holmes et al., 2008a) (Table 1). Alignments of the human CES subunits showed between 39-46\% sequence identities, which suggests that these are products of separate but related gene families, whereas sequence alignments of human CES1 and CES2 with mouse CES1-like and CES2-like subunits exhibited higher levels of sequence identities with the CES family homolog in each case (66-78\% identities for human and mouse CES1-like subunits and 64-72\% for human and mouse CES2-like subunits, respectively) (data not shown), suggesting that these are members of the same mammalian CES families, in each case. Similar results were observed for comparisons of human CES3, CES4A (previously CES6 or CES8) and CES5A (previously 


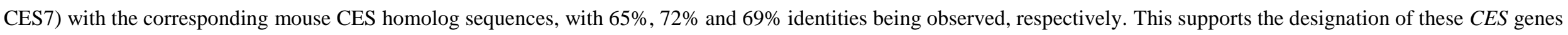
being members of the same family, in each case.

The amino acid sequences for the human CES subunits examined contained 567 (CES1), 559 (CES2), 571 (CES3), 561 (CES4A) and 575 (CES5A) residues (Figure 1). Previous studies on human CES1 have identified key residues which contribute to the catalytic, oligomeric, subcellular localization and regulatory functions for this enzyme (sequence numbers refer to human CES1). These included the catalytic triad for the active site (Ser221; Glu354; His468) (Cygler et al. 1993); disulfide bond forming residues

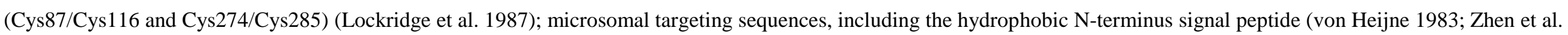
1995; Potter et al. 1998) and the C-terminal endoplasmic reticulum (ER) retention sequence (His-Ile-Glu-Leu) (Robbi \& Beaufay 1983); as well as ligand binding sites, including the 'Z-site' (Gly356), the 'side door' (Val424-Met425-Phe426) and the 'gate' (Phe550) residues (Bencharit et al. 2003; 2006; Fleming et al. 2005). Identical residues were observed for each of the human CES subunit families for the active site triad and disulfide bond forming residues although changes were observed for some key residues for CES1 subunits, including the 'side-door' and 'gate' of the active site, with family specific sequences or residues in each case; the 'Z-site' (Gly356 for human CES1) has been retained for human CES2 and CES5A sequences, but substituted for CES3 (Ser) and CES4A (Asn); the hydrophobic N-terminal sequence for human CES sequences has undergone major changes although this region retains a predicted signal peptide property; the human CES C-terminal tetrapeptide sequences have also changed, although CES2 (HTEL) and CES3 (QEDL) are similar in sequence with human CES1 (HIEL), which plays a role in the localization of human CES1 within endoplasmic reticulum membranes (Robbi \& Beaufay, 1983).

Other key human CES1 sequences included two charge clamps which are responsible for subunit-subunit interaction, namely residues Lys78/Glu183 and Glu72/ which Arg186, contribute to the trimeric and hexameric structures for this enzyme (Bencharit et al. 2003; 2006; Fleming et al. 2005). Other human CES subunit sequences for these charge clamp sites included substitutions with neutral amino acids for the human CES2 and CES5A sequences, while the CES3 and CES4A sequences retained one potential clamp site (Figure 1). Pindel et al. (1997) and Holmes et al (2009b) have reported monomeric subunit structures for human and baboon CES2, which is consistent with the absence of charge clamps for this enzyme. This could have a major influence on the kinetics and biochemical roles for human CES isozymes since three dimensional studies have 
indicated that ligand binding to the human CES1 'Z-site' shifts the trimer-hexamer equilibrium towards the trimer facilitating substrate binding and enzyme catalysis (Redinbo \& Potter 2005). The N-glycosylation site for human CES1 at Asn79-Ala80-Thr81 (Kroetz et al. 1993; Bencharit et al. 2003; 2006; Fleming et al. 2005) was not retained for any of the other human CES sequences, although potential N-glycosylation sites were observed at other positions, including CES2 (site 3), CES3 (site 2), CES4A (sites 4, 5 and 7) and CES5A (sites 6, 8 and 9) (Table 4). Given the reported role of the N-glycosylated carbohydrate group contributing to CES1 stability and maintaining catalytic efficiency (Kroetz et al. 1993), the N-glycosylation sites predicted for other human CES subunits may perform similar functions or indeed may serve new functions specific to a particular CES family.

Predicted secondary structures for human CES2 (Holmes et al., 2009b), CES3 (Holmes et al., 2010), CES4A (Holmes et al., 2009a) and CES5A (Holmes et al., 2008a) sequences were compared with those reported for human CES1 and similar $\alpha$-helix $\beta$-sheet structures were observed for all of the CES subunits examined (Bencharit et al., 2003; 2006) (Figure 1). This was especially apparent near key residues or functional domains such as the $\alpha$-helix within the N-terminal signal peptide; the $\beta$-sheet and $\alpha$-helix structures near the active site Ser221 (human CES1) and 'Z-site' (Glu354/Gly356 respectively); the $\alpha$-helices bordering the 'side door' site; and the $\alpha$-helix containing the 'gate' residue (Phe550 for human CES1). The human CES5A sequence, however, contained a predicted helix at the hydrophobic C-terminus not observed for other CES subunits which may perform a family specific function. Predicted 3-D structures have been previously described for each of the human CES subunits (Holmes et al., 2008a; 2009a, b; 2010) which were similar to the human CES1 structure (Bencharit et al., 2003; 2006).

\section{MOUSE Ces GENES AND ENZYMES}

Table 2 summarizes the proposed names, locations and overall structures for the Ces genes observed for the mouse genome (July 2007 mouse [Mus musculus] genome data obtained from the Build 37 assembly by NCBI and the Mouse Genome Sequencing Consortium) (http://www.ncbi.nlm.nih.gov was used in this study). The italicized gene name, 'Ces', is consistent with other mouse gene nomenclature and is preferred to the 'CES' stem used for human genes. At least 20 mouse $C e s$ genes are recognized on the

Mouse Genome Database (http://www.informatics.jax.org/) (MGI) and further described in terms of their locations on mouse chromosome 8, the number of predicted exons for each gene, predicted strand for transcription, number of amino acid residues and subunit MWs for the encoded CES subunits, and identification symbols from MGI (eg. 
MGI3648919 for Cesla), NCBI (Reference Sequences were identified from the National Center for Biotechnology Information database) (http://www.ncbi.nlm.nih.gov/), Vega (the Vertebrate Genome Annotation (VEGA) database) (http://vega.sanger.ac.uk/index.html), UNIPROT (Universal Protein Resource) (http://www.ebi.ac.uk/uniprot/) and Ensembl (Genome Database) (http://www.ensembl.org/) database sources.

Eight Ces1-like genes are located in tandem within a 360 kilobase segment of mouse chromosome 8 , with an average gene size of 28 kilobases. The names for these genes (Cesla, Ces1b...Ceslh) are allocated in the same order as their locations on the mouse genome (Table 3). The Cesl-like gene cluster is also located near to the mouse Ces5a gene, which is comparable to the CES1P1-CES1-CES5A cluster observed for human chromosome 16 . Each of these genes contained 13 or 14 exons predicted for transcription on the negative strand, and with encoded CES subunits exhibiting distinct but similar amino acid sequences (554-567 residues). The subunits were 63-85\% identical with each other and with the human CES1 sequence, which is consistent with these being members of the mouse Ces1 gene family. Mouse Ces1-like genes included several that have been previously investigated, including Ceslc (previously called Es1), encoding a major mouse plasma esterase with 554 amino acid residues and also exhibiting lung surfactant convertase activity (Genetta et al., 1988; Krishnasamy et al., 1998); Cesld (previously Ces3), encoding a mouse liver enzyme with 565 residues exhibiting triacylglycerol hydrolase activity (Dolinsky et al., 2001); Cesle (previously called Es22 or egasyn) encoding a liver CES with 562 residues exhibiting $\beta$-glucuronidase-binding properties (Ovnic et al., 1991); and Ceslg (previously Cesl) encoding a liver CES which exhibits lipid metabolising activity and has 565 amino acid residues (Table 5) (Ellingham et al., 1998).

Eight Ces2-like genes were also observed in a second $286 \mathrm{~kb}$ gene cluster on mouse chromosome 8 with an average gene size of $\sim 8$ kilobases (Table 2). These genes were named according to their sequence of position on the mouse genome (Ces $2 a$, Ces $2 b \ldots . . C e s 2 h)$, and included a pseudogene designated as $C e s 2 d-p s$. Three of these mouse

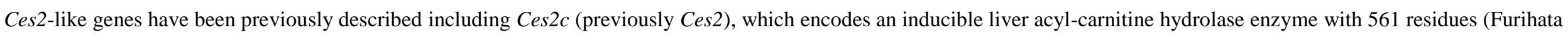
et al., 2003); Ces2e (previously Ces5) encoding a liver and intestinal enzyme with 560 amino acid residues (The MGC Project Team, 2004); and Ces2a (previously Ces6),

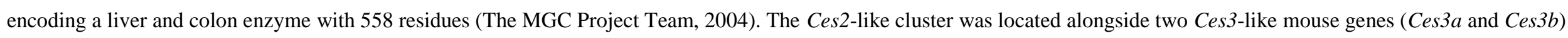
and a Ces4a gene (Table 3), which is comparable with the CES2-CES3-CES4A gene cluster on human chromosome 16 (Table 1). The Ces3a gene (previously mouse esterase 31 
or Est31) is expressed strongly in male mouse livers and encodes a 554 residue CES3-like subunit (Aida et al., 1993), whereas the Ces3b gene (previously Es31L or EG13909) is also expressed in liver encoding a 568 residue subunit (The MGC Project Team, 2004). The Ces4a gene (previously called EST8 or Ces8) encodes an enzyme predicted for secretion in epidermal cells with 563 amino acid residues showing 72\% identity with human CES4A (The MGC Project Team, 2004).

\section{RAT Ces GENES AND ENZYMES}

Table 3 summarizes the proposed names, locations and structures for Ces genes observed for the rat genome (the November 2004 rat (Rattus norvegicus) genome assembly based on version 3.4 produced by the Baylor Human Genome Sequencing Center) (Gibbs et al., 2004 was used in this study). Fifteen rat Ces genes were identified on the Rat Genome Database (RGD) (http://rgd.mcw.edu/ ) and further characterized by their locations on rat chromosomes 1 and 19, the number of predicted exons for each gene, the predicted strand for transcription, current gene symbols, the number of amino acid residues and subunit MWs for the encoded CES subunits, and the identification symbols from RGD (eg. RGD1583671 for Cesla), NCBI Reference Sequences (http://www.ncbi.nlm.nih.gov/), Vega (http://vega.sanger.ac.uk/index.html), UNIPROT (http://www.ebi.ac.uk/uniprot/) and Ensembl (http://www.ensembl.org/) database sources.

Five Cesl-like genes were located in tandem within a 201 kilobase segment of rat chromosome 19, with an average gene size of 33 kilobases (Table 3 ). The names for these genes (Cesla, Ceslc...Ceslf) were allocated according to their degree of identity with the corresponding mouse Cesl-like genes (Table 3). The genes were located in tandem in the same order as the mouse Ces1-like genes and were near the rat Ces5a gene. This is comparable to the CES1P1-CES1A-CES5A gene cluster observed for human

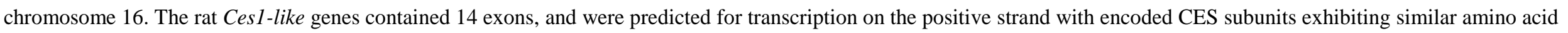

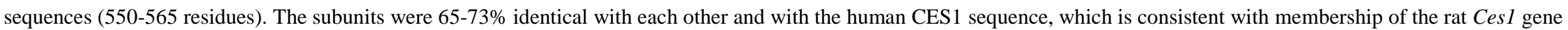
family. The encoded rat Cesl-like subunit sequences showed higher levels of identity with the corresponding mouse Cesl-like sequences (81-92\% for rat and mouse CES1a, CES1c, CES1d, CES1e and CES1f amino acid sequences). At least 3 rat Ces1-like genes have been previously described, including Ces1c (previously called Es1) encoding a rat plasma esterase (Vanlith et al., 1993; Sanghani et al., 2002); Cesld (previously Ces3) encoding a rat liver enzyme with 565 residues and exhibiting cholesteryl ester hydrolase 
activity (Robbi et al., 1990; Ghosh et al., 1995); and Cesle (previously called ES-3 or egasyn), encoding a rat liver Ces with 561 residues and having $\beta$-glucuronidase-binding properties (Robbi \& Beaufay, 1994).

Seven rat Ces2-like genes were observed on the rat genome which were localized on two chromosomes: chromosome 1 (Ces $2 c$ and $C e s 2 i)$ and chromosome 19 in 3 locations: Ces $2 a$ and $\operatorname{Ces} 2 e$; $\operatorname{Ces} 2 j$; and $\operatorname{Ces} 2 g$ and $\operatorname{Ces} 2 h$ (Table 3). The genes were named according to the degree of sequence identity with the corresponding mouse Ces2-like genes. Rat Ces2-like genes have been previously investigated, including Ces2c (previously Ces2), encoding an inducible liver acyl-carnitine hydrolase enzyme containing 561 residues (Furihata et al., 2003); Ces2e (previously Ces5) encoding a liver and intestinal enzyme with 560 amino acid residues (The MGC Project Team, 2004); and Ces2a

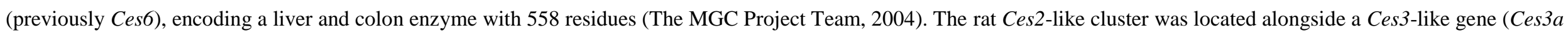
and Ces $3 b$ ) and a Ces4a gene (Table 3), which is comparable with the CES2A-CES3A-CES4A gene cluster on human chromosome 16 (Table 1).

\section{FUNCTIONS OF MAMMALIAN CES FAMILIES}

Mammalian CES families exhibit broad substrate specificities and specific roles for these enzymes have been difficult to establish because of the promiscuity of the CES active site towards a wide range of substrates and the existence of multiple forms with overlapping specificities (see Leinweber, 1987; Satoh \& Hosokawa, 1998; 2006; Redinbo $\&$ Potter, 2005; Fleming et al., 2005; Imai, 2006). Table 4 summarizes current knowledge concerning substrates and functions reported for human, mouse and rat $C E S$ gene family members.

Studies on human CES1 have examined its role in the metabolism of various drugs, including narcotics such as heroin and cocaine (Pindel et al, 1997; Bencharit et al, 2003), warfare nerve agents (Hemmert et al., 2010), psychostimulants (Sun et al, 2004), analgesics (Takai et al., 1997) and chemotherapy drugs (Sanghani et al., 2004). Mammalian liver is predominantly responsible for drug clearance from the body with CES1 and CES2 (with CES1 > CES2) playing major roles, following absorption of drugs into the circulation (Pindel et al. 1997; Imai 2006). Mammalian intestine (with CES2 > CES1) plays a major role in first pass clearance of several drugs, predominantly via CES2 in the ileum and jejunum (Imai et al. 2003). CES1 and CES2 also have different roles in prodrug activation, as shown for the anti-cancer drug irinotecan (CPT-11) which is converted to its active form SN-38 predominantly by CES2 (Humerickhouse et al. 2000). Recent modeling studies have shown that the human CES2 active site cavity is lined 
with negatively charged residues which may explain the preference of this enzyme for neutral substrates (Vistoli et al., 2010). The role for human CES3 has not been extensively studied although the enzyme is capable of activating prodrugs such as irinotecan (Sanghani et al., 2004). There are no reports concerning the metabolic role(s) for human CES4A and functional studies on mammalian CES5 function are limited to feline species, where the enzyme is secreted into cat urine and apparently regulates the production of a cat specific amino acid 'felinine', a putative pheromone precursor (Miyazaki et al. 2006)

\section{EVOLUTION OF MAMMALIAN CES GENE FAMILIES}

Recent comparative and evolutionary studies (Holmes et al., 2008b; Williams et al., 2010) have concluded that there at least five major mammalian CES gene families. In addition, the gene duplication events which generated the ancestral mammalian CES1, CES2, CES3, CES4 and CES5 genes have apparently predated the common ancestor for marsupial and eutherian mammals (Holmes et al., 2008b) which has been estimated at 173-193 million years ago (Woodburne et al, 2003) and may coincide with the early diversification of tetrapods approximately 350-360 million years ago (Donoghue \& Benton, 2007). The mammalian CES gene families are ancient in their genetic origins and were established prior to the appearance of mammals during evolution. Further CES/Ces gene duplication events have subsequently occurred during mammalian evolution however, especially for rodent species, for which the mouse and rat Ces1-like and Ces2-like genes have apparently undergone successive duplication events. At least three of these are likely to have occurred in the common ancestor for rat and mouse during rodent evolution since several homolog genes and proteins were recognized, including Ces $1 c$ (previously Es1), Cesld (Ces3), Ces1e (Es22), Ces2a (Ces6), Ces2c (Ces2) and Ces2e (Ces5) (Tables 3 and 4). With the exception of the rat Ces2-like genes, which were located in multiple clusters on chromosomes 1 and 19, human, mouse and rat CES genes were localized within 2 clusters of genes on the same chromosome, namely Ces 1 -Ces5A (with multiple Ces1-like genes) and Ces2-Ces3-Ces4A (with multiple Ces2-like genes in mouse and rat). The presence of two Ces3-like genes in the mouse suggests that a further duplication event also took place in this species.

\section{CONCLUSIONS}


This paper has examined human, mouse and rat carboxylesterase genes and encoded subunits and has proposed a new nomenclature system identifying each of five gene families (designated as CES1, CES2 ...CES5 for human genes or Ces1, Ces2...Ces 5 for mouse and rat genes) and allocating a unique gene name for each of the genes. The italicized root symbol " $C E S$ " for human and "Ces" for mouse and rat genes followed by a number for the family were used which is consistent with current practice. When multiple genes were identified for a gene family or where a gene required a name which clashed with an existing name, a capital letter (for human genes) (eg. CES4A) or a lower case letter (for mouse and rat genes) (eg. Cesla, Ceslb) was added after the number. A human CES pseudogene was named using a capital "P" and a number (eg. CES1P1), whereas mouse and rat Ces pseudogenes were named with a unique lower case letter followed by “-ps" (eg. Ces2d-ps). This new nomenclature will also assist in naming multiple CES genes and proteins from other mammalian species. As an example, Holmes and co-workers (2009c) and Williams et al (2010) have reported multiple CES1-like genes on the horse genome which may be designated in accordance with the recommended nomenclature as CES1A, CESIB, CESIC etc in order of the tandem locations of these genes on chromosome 3. Transcript isoforms of CES gene transcripts were named by following the gene name with the Genbank ID for the specific transcript. This nomenclature will assist our understanding of the genetic relatedness and the CES family origins for individual human, mouse and rat CES genes and proteins and facilitate future research into the structure, function and evolution of these genes. It will also serve as a model for naming $C E S$ genes from other mammalian species.

\section{ACKNOWLEDGEMENTS}

This research was supported by NIH Grants P01 HL028972 and P51 RR013986 (to LAC) and CA108775, and a Cancer Center Core Grant CA21765, the American Lebanese and Syrian Associated Charities (ALSAC) and St. Jude Children's Research Hospital (SJCRH) (to PMP).

\section{REFERENCES}

Aida K, Moore R, Negishi M (1993) Cloning and nucleotide sequence of a novel, male-predominant carboxylesterase in mouse liver. Biochim Biophys Acta 1174, 72-74

Barthel BL, Torres RC, Hyatt JL, Edwards CC, Hatfield MJ, Potter PM, Koch TH (2008) Identification of human intestinal carboxylesterase as the primary enzyme for activation of a doxazoline carbamate prodrug. J Med Chem 51, 298-304 
Becker A, Bottcher A, Lackner KJ, Fehringer P, Notka F, Aslandis C, Schmithz C (1994) Purification, cloning and expression of a human enzyme with acyl coenzyme A: cholesterol acyltransferase activity, which is identical to liver carboxylesterase. Arterioscler Thromb 14, 1346-1355

Bencharit S, Morton C.L, Xue Y, Potter PM, Redinbo MR (2003) Structural basis of heroin and cocaine metabolism by a promiscuous human drug-processing enzyme. Nature Struct Biol 10, 349-356

Bencharit S, Edwards CC, Morton CL, Howard-Williams EL, Kuhn P, Potter PM, Redinbo MR (2006) Multisite promiscuity in the processing of endogenous substrates by human carboxylesterase 1. J Mol Biol 363, 201-214

Berning W, De Looze SM, von Deimling O (1985) Identification and development of a genetically closely linked carboxylesterase gene family of the mouse liver. Comp Biochem Physiol, 80, 859-865

Cygler M, Schrag JD, Sussman JL, Harel M, Silman I, Gentry MK, Dostor BP (1993) Relationship between sequence conservation and three-dimensional structure in a large family of esterases, lipases and related proteins. Protein Science 2, 366-382

Diczfalusy MA, Bjorkkem I, Einarsson C, Hillebrant CG, Alexson SE (2001) Characterization of enzymes involved in formation of ethyl esters of long-chain fatty acids. J Lipid Res 42, 1025-1032

Dolinsky VW, Sipione S, Lehner R, Vance DE (2001) The cloning and expression of murine triacylglycerol hydrolase cDNA and the structure of the corresponding gene. Biochim Biophys Acta 1532, 162-172

Donoghue PCJ, Benton MJ (2007) Rocks and clocks: calibrating the tree of life using fossils and molecules. Trends Genet 22, 424- 630

Ecroyd H, Belghazi M, Dacheux J-L, Miyazaki M, Yamashita T, Gatti JL (2006) An epididymal form of cauxin, a carboxylesterase-like enzyme, is present and active in mammalian male reproductive fluids. Biol Reprod 74, 439-447.

Ellingham P, Seedorf U, Assmann G (1998) Cloning and sequencing of a novel murine liver carboxylesterase cDNA. Biochim. Biophys. Acta 1397, 175-179

Fleming C.D, Bencharit S, Edwards CC, Hyatt JL, Tsurkan L, Bai F, Fraga C, Morton CL, Howard-Williams EL, Potter PM, Redinbo MR (2005) Structural insights into drug processing by human carboxylesterase 1: tamoxifen, Mevaststin, and inhibition by Benzil. J Mol Biol 352, 165-177

Fukami T, Nakajima M, Maruichi T, Takahashi S, Takamiya M, Aoki Y, McLeod HL, Yokoi T (2008) Structure and characterization of human carboxylesterase 1A1, 1A2 and $1 \mathrm{~A} 3$ genes. Pharm Genomics 18, 911-920

Furihata T, Hosokawa M, Nakata F, Satoh T, Chiba K (2003) Purification, molecular cloning, and functional expression of inducible liver acylcarnitine hydrolase in C57BL/6 mouse, belonging to the carboxylesterase multigene family. Arch Biochem Biophys 416, 101-109 
Genetta T.L, D'Eustachio P, Kadner SS, Finlay TH (1988) cDNA cloning of esterase 1, the major esterase activity in mouse plasma. Biochem Biophys Res Commun 151, $1364-1370$

Ghosh S (2000) Cholesteryl ester hydrolase in human monocyte/macrophage: cloning, sequencing and expression of full-length cDNA. Physiol Genomics 2, 1-8

Ghosh S, Mallonee DH, Grogan W.M (1995) Molecular cloning and expression of rat hepatic neutral cholesteryl ester hydrolase. Biochim Biophys Acta 1259, 305-312

Gibbs RA, Weinstock GM, Metzker ML, Muzny DM, Sodergren EJ, Scherer S, Scott G, Steffen D, Worley KC. (2004) Genome sequence of the Brown Norway rat yields insights into mammalian evolution. Nature 428:493-521

Gilham D, Alam, M, Gao W, Vance DE, Lehner R (2005) Triacylglycerol hydrolase is localized to the endoplasmic reticulum by an unusual retrieval sequence where it participates in VLDL assembly without utilizing VLDL lipids as substrates. Mol Biol Cell 16, 984-996

Hemmert AC, Otto TC, Wierdl M, Edwards CC, Fleming CD, MacDonald M, Cashman JR, Potter PM, Cerasoli DM, Redinbo MR (2010) Human carboxylesterase 1 stereoselectively binds the nerve agent cyclosarin and spontaneously hydrolyzes the nerve agent sarin. Mol Pharmacol 77, 508-516

Holmes RS, Cox LA, VandeBerg JL (2008a) Mammalian carboxylesterase 5: comparative biochemistry and genomics. Comp Biochem Physiol Part D 3, 195-204

Holmes RS, Chan J, Cox LA, Murphy WJ, VandeBerg JL (2008b) Opossum carboxylesterases: sequences, phylogeny and evidence for CES duplication events predating the marsupial-eutherian common ancestor. BMC Evol Biol 8, 54

Holmes RS, VandeBerg JL, Cox LA (2009a) A new class of mammalian carboxylesterase CES6. Comp Biochem Physiol Part D 4, $209-217$

Holmes RS, Glenn JP, VandeBerg JL, Cox LA (2009b) Baboon carboxylesterases 1 and 2: sequences, structures and phylogenetic relationships with human and other primate carboxylesterases. J Med Primatol 38, 27-38

Holmes RS, Cox LA, VandeBerg JL (2009c) Horse carboxylesterases: evidence for six CES1 and four families of CES genes on chromosome 3. Comp Biochem Physiol 4: 54-65

Holmes RS, Cox LA, VandeBerg JL (2010) Mammalian carboxylesterase 3: comparative genomics and proteomics. Genetica DOI 10.1007/s10709-101-9438-z (in press)

Hosokawa M, Furihata T, Yaginuma Y, Yamamoto N, Kayano N, Fujii A, Nagahara Y, Satoh T, Chiba K

(2007) Genomic structure and transcriptional regulation of the rat, mouse and human carboxylesterase genes. Drug Metab Revs 39, 1-15

Hosokawa M (2008) Structure and catalytic properties of carboxylesterase isozymes involved in metabolic activation of prodrugs. Molecules 13, 412-431 
Hosokawa M, Furihata T, Yaginuma Y, Yamamoto N, Watanabe N, Tsukada E, Ohhata Y, Kobayashi K, Satoh T, Chiba K (2008) Structure organization and characterization of the regulatory element of the human carboxylesterase (CES1A1 and CES1A2) genes. Drug Metab Pharmacogenet 23, 73-84

Humerickhouse R, Lohrbach K, Li L, Bosron WF, Dolan ME (2000) Characterization of CPT-11 hydrolysis by human liver carboxylesterase isoforms h-CE1 and hCE-2. Cancer Res 60, 1189-1192

Imai T (2006) Human carboxylesterase isozymes: catalytic properties and rational drug design. Drug Metab Pharmacogen 21, 173-185

Imai T, Yoshigae Y, Hosokawa M, Chiba K, Otagiri M (2003) Evidence for the involvement of a pulmonary first-pass effect via carboxylesterase in the disposition of a propanolol ester derivative after intravenous administration. J Pharmacol Exp Therapeut 307, 1234-1242

Ko KW, Erickson B, Lehner R (2009) Es-x/Ces1 prevents triacylglycerol accumulation in McArdle-RH7777 hepatocytes. Biochim Biophys Acta 1791, 1133-1143

Krishnasamy R, Teng AL, Dhand R, Schultz RM, Gross NJ (1998) Molecular cloning, characterization and differential expression pattern of mouse lung surfactant convertase. Am J Physiol Lung Mol Cell Biol 275, L969-L975

Kroetz DL, McBride OW, Gonzalez FJ (1993) Glycosylation-dependent activity of Baculovirus-expressed human liver carboxylesterases: cDNA cloning and characterization of two highly similar enzyme forms. Biochem 32, 11606-11617

Langmann T, Becker A, Aslanidis C, Notka F, Ulrich H, Schwer H, Schcmitz G (1997) Structural organization and characterization of the promoter region of a human carboxylesterase gene. Biochim Biophys Acta 1350, 65-74

Lehner R, Vance DE (1999) Cloning and expression of a cDNA encoding a hepatic microsomal lipase that mobilizes stored triacylglycerol. Biochem J 343, 1-10.

Leinweber FJ (1987) Possible physiological roles of carboxyl ester hydrolases. Drug Metab Revs 18, 379-439.

Linke T, Dawson H, Harrison EH (2005) Isolation and characterization of a microsomal retinyl ester hydrolase. J Biol Chem 280, 23287-23294

Lockridge O, Adkins S, La Due BN (1987) Location of disulfide bonds within the sequence of human serum cholinesterase. J Biol Chem 262, 12945-12952

Marsh S, Xiao M, Yu J, Ahluwalia R, Minton M, Freimuth RR, Kwok P-Y, McLeod HL (2004) Pharmacogenomic assessment of carboxylesterases 1 and 2. Genomics 84, $661-668$

Masaki K, Hashimoto M, Imai (2007) Intestinal first-pass metabolism via carboxylesterase in rat jejunum and intestine. Drug Metab Dispos 35, 1089-1095 
Miyazaki M, Yamashita T, Suzuki Y, Saito Y, Soeta S, Taira H, Suzuki A (2006) A major urinary protein of the domestic cat regulates the production of felinine, a putative pheromone precursor. Chem Biol 13, 1070-1079

Morton CL, Iacono L, Hyatt JL, Taylor KR, Cheshire PJ, Houghton PJ, Danks MK, Stewart CF, Potter PM (2005) Activation and antitumor activity of CPT-11 in plasma esterase-deficient mice. Cancer Chemother Pharmacol. 56, 629-36

Miyazaki M, Kamiie K, Soeta S, Taira H, Yamashita T (2003) Molecular cloning and characterization of a novel carboxylesterase-like protein that is physiologically present at high concentrations in the urine of domestic cats (Felis Catus). Biochem J 370, 101-110

Miyazaki K, Yamashita T, Suzuki Y, Saito Y, Soeta S, Taira H, Suzuki A (2006) A major urinary protein of the domestic cat regulates the production the production of felinine, a putative pheromone precursor. Chem Biol 13, 10171-10179

Munger JS, Shi GP, Mark EA, Chin DT, Gerard C, Chapman HA (1991) A serine esterase released by human alveolar macrophages is closely related to liver microsomal carboxylesterases. J Biol Chem 266, 18832-18838

Mutch E, Nave R, McCracken N, Zech K, Williams FM (2007) The role of esterases in the metabolism of ciclesinide to deisobutyrl-ciclesonide in human tissue. Biochem Pharmacol 73, 1657-1664

Ohtsuka H, Inoue S, Kameyama M (2003) Intracellular conversion of irinotecan to its active form, SN-38, by native carboxylesterase in human non-small cell lung cancer. Lung Cancer 41, 87-198

Okazaki H, Igarashi M, Nishi M, Tajima M, Sekiya M, Okazaki S, Yahagi N, Ohashi K, Tsukamoto K, Michiyo A-K, Yamada N, Aoki J, Moriwawa R, Takanezawa Y, Arai H, Nagai R, Kadowaki T, Osuga J, Ishibashi S (2006) Identification of a Novel Member of the Carboxylesterase Family That Hydrolyzes Triacylglycerol. A Potential Role in Adipocyte Lipolysis Diabetes 55, 2091-2097

Okazaki H, Igarashi M, Nishi M, Sekiya M, Tajima M, Takase S, Takanashi M, Ohta K, Tamura Y, Okazaki S, Yahagi N, Ohashi K (2008) Identification of neutral cholesterol hydrolase, a key enzyme removing cholesterol from macrophages. J Biol Chem 283, 33357-33364

Ovnic M., Swank R.T., Fletcher C., Zhen L., Novak E.K., Baumann H., Heintz N., Ganschow R.E. (1991) Characterization and functional expression of a cDNA encoding egasyn (esterase-22): the endoplasmic reticulum-targeting protein of beta-glucuronidase. Genomics 11, 956-967

Pindel EV, Kedishvili NY, Abraham TL, Brezinski MR, Zhang A, Dean RA, Bosron WF (1997) Purification and cloning of a broad substrate specificity human liver carboxylesterase that catalyzes the hydrolysis of cocaine and heroin. J Biol Chem 272, 14769-14775

Potter P.M, Wolverton JS, Morton CL, Wierdl M, Danks MK (1998) Cellular localization domains of a rabbit and human carboxylesterase: influence on irinotecan (CPT-11) metabolism by the rabbit enzyme. Cancer Res 58, 3627-32 
Redinbo MR, Potter PN (2005) Mammalian carboxylesterases: from drug targets to protein therapeutics. Drug Discovery Today 10, 313-20

Rhead B, Karolchik D, Kuhn RM, Hinrichs AS, Zweig AS, Fujita P, Diekhans M, Smith KE, Rosenbloom KR, Raney BJ, Pohl A, Pheasant M, Meyer L, Hsu F, HillmanJackson J, Harte RA, Giardine B, Dreszer T, Clawson H, Barber GP, Haussler D, Kent WJ (2010) The UCSC Genome Browser database: update 2010. Nucleic Acids Res 38: D613-9

Robbi M., Beaufay H. (1994) Cloning and sequencing of rat liver carboxylesterase ES-3 (egasyn). Biochem Biophys Res Commun 203, 1404-1411

Robbi M, Beaufay H, Octave J-N (1990) Nucleotide sequence of cDNA coding for rat liver pI 6.1 esterase (ES-10), a carboxylesterase located in the lumen of the endoplasmic reticulum. Biochem J 269, 451-458

Ruppert C, Bagheri A, Markart P, Schmidt R, Seegar W, Gunther A (2006) Liver carboxylesterase cleaves surfactant protein (SP-B) and promotes surfactant subtype conversion. Biochem Biophys Res Coms 348, 1449-1454

Sanghani SP, Davis WI, Dumaual NG, Mahrenholz A, Bosron WF (2002) Identification of microsomal rat liver carboxylesterases and their activity with retinyl palmitate (2002) Eur J Biochem 269, 4387-4398

Sanghani SP, Quinney SK, Fredenberg TB, Davis WI, Murray DJ, Bosron WF (2004) Hydrolysis of irinotecan and its oxidative metabolites, 7-ethyl-10-[4-N(5aminopentanoic acid)-1-piperidino] carbonyloxycampothecin and 7-ethyl-10-[4-(1-piperidino)-1 amino]-carbonyloxycamptothecin, by human carboxylesterases CES1A1, CES2, and a newly expressed carboxylesterase isoenzyme, CES3. Drug Metab Dispos 32, 505-511

Satoh T, Hosokawa M (1998) The mammalian carboxylesterases: from molecules to functions. Ann Revs Pharmacol Toxicol 38, 257-288

Satoh T, Hosokawa M (2006) Structure, function and regulation of carboxylesterases. Chem-Biol Interactions 162, 195-211

Satoh T, Taylor P, Bosron WF, Sanghani P, Hosokawa M, Du PB (2002) Current progress on esterases: from molecular structure to function. Drug Metab Dispos 30, 488493

Schewer H, Langmann T, Daig R, Becker A, Aslandis C, Schmidt G (1997) Molecular cloning and characterization of a novel putative carboxylesterase, present in human intestine and liver. Biochem Biophys Res Commun 233, 117-120

Schreiber R, Taschler U, Wolinski H, Seper A, Tamegger SN, Graf M, Kohlwein SD, Haemmerle G, Zimmermann R, Zechner R, Lass A (2009) Esterase 22 and betaglucuronidase hydrolyze retinoids in mouse liver. J Lipid Res 50, 2514-2523

Shibita F, Takagi Y, Kitajima M, Kuroda T, Omura T (1993) Molecular cloning and characterization of a human carboxylesterase gene. Genomics 17, 76-82 
Sun Z., Murry DJ, Sanghani SP, Davis WI, Kedishvilli NY, Zou Q, Hurley TD, Bosron WF (2004) Methylphenadate is stereoselectively hydrolyzed by human carboxylesterase CES1A1. J Pharmcol Exp Ther 310, 469-476

Takai S, Matsuda A, Usami Y, Adachi T, Sugiyama T, Katagiri Y, Tatematsu M, Hirano (1997) Hydrolytic profile for ester- or amide-linkage by carboxylesterases pI 5.3 and 4.5 from human liver. Biol Pharm Bull 20, 869-873

Taketani M, Shii M, Ohura K, Ninomiya S, Imai T (2007) Carboxylesterase in the liver and small intestine of experimental animals and human. Life Sci 81: 924-932

The MGC Project Team. (2004) The status, quality, and expansion of the NIH full-length cDNA project: the Mammalian Gene Collection (MGC). Genome Res 14, 21212127

Thierry-Mieg D, Thierry-Mieg J (2006) AceView: A comprehensive cDNA-supported gene and transcripts annotation. Genome Biology 7, S12 http://www.ncbi.nlm.nih.gov/IEB/Research/Acembly/index.html?human

Tanimoto K, Kaneyasu M, Shimokuni T, Hiyama K, Nishiyama M. (2007) Human carboxylesterase 1A2 expressed from carboxylesterase 1A1 and 1A2 genes is a potent predictor of CPT-11 cytotoxicity in vitro. Pharm Genomics 17, 1-10

Tsujita T, Okuda H (1993) Palmitoyl-coenzyme A hydrolyzing activity in rat kidney and its relationship with carboxylesterase. J Lipid Res 34, 1773-1781

Vanlith H A, Haller M, Vanhoof IJM, Vanderwouw MJA, Vanzutphen BFM, Beynen AC (1993) Characterization of rat plasma esterase ES-1A concerning its molecular and catalytic properties. Arch Biochem Biophys 301, 265-274

Vistoli G, Padretti A, Mazzolari A, Testa B (2010) Homology modelling and metabolism prediction of human carboxylesterase-2 using docking analyses by GriDock: a parrallelized tool based on AutoDock 4.0. J Comput Aided Mol Des PMID: 20623318

von Heijne G (1983) Patterns of amino acids near signal-sequence cleavage sites. Eur J Biochem 133, 17-21

Wang H, Gilham D, Lehner R (2007) Proteomic and lipid characterization of apo-lipoprotein B-free luminal lipid droplets from mouse liver microsomes: implications for very low density lipoprotein assembly. J Biol Chem 282, 33218-33226

Williams ET, Wang H, Wrighton SA, Qian Y-W, Perkins EJ (2010) Genomic analysis of the carboxylesterases: identification and classification of novel forms. Mol Phylogenet Evol doi:10.1016/j.j.ympev.2010.05.018

Woodburne MO, Rich TH, Springer MS (2003) The evolution of tribospheny and the antiquity of mammalian clades. Mol Phylogenet Evol 28,360-385 
Xu G, Zhang W, Ma, MK, MacLeod HL (2002) Human carboxylesterase 2 is commonly expressed in tumor tissue and is correlated with the activation of irinotecan. Clin Cancer Res 8, 2605-2611

Yan B, Matoney L, Yang D (1999) Human carboxylesterases in term placenta: enzymatic characterization, molecular cloning and evidence for the existence of multiple forms. Placenta 20, 517-525

Yoshimura M, Kimura T, Ishii M, Ishii K, Matsuura T, Geshi E, Hosokawa M, Muramatsu M (2008) Functional polymorphisms in carboxylesterase1A2 (CES1A2) gene involves specific protein 1 (Sp1) binding sites. Biochem Biophys Res Commun 369, 939-942

Zhang L, Hu Z, ZHU C, Liu Q, Zhou Y, Zhang Y (2009) Identification and characterization of an epididymis-specific gene, Ces7. Acta Biochim Biophys Sin 41:809-815

Zhen L, Rusiniak ME, Swank RT (1995) The beta-glucuronidase propeptide contains a serpin-related octamer necessary for complex formation with egasyn esterase and for retention within the endoplasmic reticulum. J Biol Chem 270, 11912-11920 


\section{Figure Legends:}

\section{Figure 1: Amino Acid Sequence Alignments for Human CES1, CES2, CES3, CES4A and CES5A Subunits}

See Table 1 for CES isoform sequences aligned; * shows identical residues for CES subunits; : similar alternate residues; . dissimilar alternate residues; signal peptide sequences for CES1 (1-17), CES2 (1-25), CES3 (1-27), CES4A (1-19) and CES5A (1-24) and C- termini (MTS) miCrosomal targeting sequences for CES1 (564-567), CES2 (556-569) and CES3 (568-571) are shown in red; active site (AS) triad residues (human CES1) Ser221, Glu354 and His468 are highlighted in green; 'Side door' (Val424-Met425-Phe426), 'Gate' (Phe550) and cholesterol binding residue (Z site) (Gly356) for human CES1 (Fleming et al, 2005) are highlighted in khaki; disulfide bond Cys residues for human CES1 (•) are shown in blue; charge clamp residues identified for human CES1 (Glu72...Arg186; Lys78...Glu183) (Fleming et al, 2005) are highlighted in purple; confirmed (CES1) (Asn79-Ala80Thr81) [site 1] or predicted N-glycosylation sites for human CES2 (Asn111-Met112-Thr113) [site 3], CES3 (Asn105-Ser106-Ser107) [site 2], CES4A (Asn213-Val214-Thr215 [site 4]; Asn276-Ser-277-Thr278) [site 5]; and Asn388-Ile389-Thr390) [site 7] and CES5A (Asn363-Lys364-Ser365 [site 6]; Asn513-Leu514-Thr515 [site 8]; and Asn524-Met525-Ser526 [site 9]) are highlighted in blue; $\alpha$-helix (human CES1 or predicted) and $\beta$-sheet (human CES1 or predicted) regions were highlighted in yellow and grey, respectively; $\alpha$-helices and $\beta$-sheets are numbered according to the reported human CES1 3D structure (Fleming et al, 2005); bold underlined font shows known or predicted exon start sites; exon numbers refer to the human CES1 gene (see Langmann et al., 1997).

\section{Figure 2: Gene Structures and Major Isoforms for Human CES1, CES2, CES3, CES4A and CES5A Genes.}

Derived from AceView website http://www.ncbi.nlm.nih.gov/IEB/Research/Acembly/ (Thierry-Mieg and Thierry-Mieg,2006) Mature isoform variants (a) are shown with capped $5^{\prime}$ - and $3^{\prime}$ - ends for the predicted mRNA sequences; exons are in solid color; 5'- and 3'- untranslated regions of the genes are shown as open boxes; introns are shown as a line; the $5^{\prime} \rightarrow 3^{\prime}$ transcription directions are shown; a refers to the major transcript isoform for each human CES gene. Note that each CES gene structure is drawn to a different scale and that the respective gene sizes are shown: CES1 [34.8kb]; CES2 [10.9kb]; CES3 [13.9kb]; CES4A [22.3kb]; and CES5A [79.3kb]. 


\section{Table Legends}

\section{Table 1: Human CES1, CES1P1, CES2, CES3, CES4A and CES5A Genes and Subunits.}

RefSeq, GenBank and UNIPROT IDs provide the sources for the gene and protein sequences; the relative gene expression level for human CES genes in comparison with the expression of an average human gene is given in [brackets] 'http://www.ncbi.nlm.nih.gov/IEB/Research/Acembly/; ${ }^{2}$ refers to GenBank ID number; ${ }^{3}$ no current AceView isoform name available; ps refers to a pseudogene (CES1P1); gene sizes are given as base pairs of nucleotides; +ve and -ve refer to the transcription strand direction; CES isoform sequences aligned in Figure 1 are shown in bold; ${ }^{4}$ the human CES2 BC032095 isoform transcript contains multiple transcription start sites with the shorter CES2 sequence (559 residues) previously reported (see Schwer et al., 1997; Pindel et al .1997).

\section{Table 2: Mouse Ces Genes and Subunits.}

RefSeq, GenBank, UNIPROT, MGI, Vega and Ensembl IDs provide the sources for the gene and protein sequences; ps refers to a pseudogene (Ces2d-ps); the relative gene expression level for mouse Ces genes in comparison with the expression of an average mouse gene is given in [brackets] http://www.ncbi.nlm.nih.gov/IEB/Research/Acembly/; gene sizes are given as base pairs of nucleotides; +ve and -ve refer to the transcription strand.

\section{Table 3: Rat Ces Genes and Subunits.}

RefSeq, GenBank, UNIPROT, RGD, Vega and Ensembl IDs provide the sources for the gene and protein sequences; gene sizes are given as base pairs of nucleotides; the relative gene expression level for rat Ces genes in comparison with the expression of an average rat gene is given in [brackets] http://WWW.ncbi.nlm.nih.gov/IEB/Research/Acembly/; tve and -ve refer to the transcription strand direction.

\section{Table 4: Functions and Substrates for Human CES, and Mouse and Rat Ces Genes and Enzymes}

${ }^{1}$ Pindel et al., 1997; ${ }^{2}$ Bencharit et al., 2003; ${ }^{3}$ Satoh \& Hosokawa, 2006; ${ }^{4}$ Sun et al., 2004; ${ }^{5}$ Takai et al., 1997; ${ }^{6}$ Humerickhouse et al., 2000; Xu et al., 2002; Ohtsuka et al., 2003; Morton et al., 2005; 'flurbiprofen derivatives serve as substrates; Imai, 2006; Taketani et al., 2007; Hosokawa, 2008; ${ }^{8}$ Diczfalusy et al., 2001; ${ }^{9}$ Hemmert et al., 2010; ${ }^{10}$ Mutch et al., 2007; ${ }^{11}$ Becker et al., 1994; ${ }^{12}$ Barthel et al., 2008 ; ${ }^{13} \mathrm{Krishnasamy}$ et al.,

1998; Ruppert et al., 2006; 14Morton et al., 2005; ${ }^{15}$ Dolinsky et al., 2005; ${ }^{16}$ Ovnic et al., 1991; ${ }^{17} \mathrm{Ellingham} \mathrm{et} \mathrm{al,} \mathrm{1998;} \mathrm{Koh} \mathrm{et} \mathrm{al,} \mathrm{2009;}$ ${ }^{18}$ Furihata et al., 2003; ${ }^{19}$ Sanghani et al., 2002; ${ }^{20}$ Ghosh et al., 1995; Okazaki et al, 2008; ${ }^{21}$ Robbi \& Beaufay, 1994; ${ }^{22}$ Masaki et al., 2007;

${ }^{23}$ Miyazaki et al., 2006; ${ }^{24}$ Ecroyd et al., 2006; Zhang et al., $2009{ }^{25}$ Gilham et al., 2005; ${ }^{26}$ Schreiber et al., 2009; ${ }^{27}$ Lehner \& Vance, 1999; ${ }^{28}$ Okazaki et al., 2006; ${ }^{29} \mathrm{Linke}$ et al., 2005. 
Figure 1

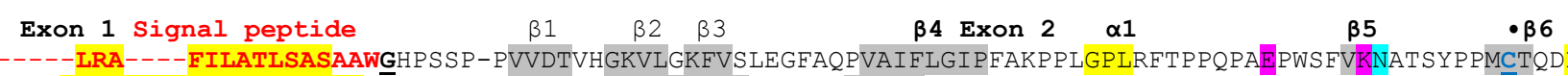

$\alpha 2$

Exon $3 \quad \beta 7$

CES1 MW-----LRA----FILATLSASAAWGHPSSP-PVVDTVHGKVLGKFVSLEGFAQPVAIFLGIPFAKPPLGPLRFTPPQPAEPWSFVKNATSYPPMCTQDPKAGQLLSELFT-NRKENIP 109 CES2 MR--LHRLRARLSAVACGLLLLLVRGQGQDSASPIRTTHTGQVLGSLVHVKGANAGVQTELGIPFAKPPLGPLRFAPPEPPESWSGVRDGTTHPAMCLQDL--TAVESEFLSQFNMTFPS 116 CES3 MERAVRVESGVLVGVCLLLACPATATG GEVAQPEVDTTLGRVRGRQVGVKGTDRLVNVFLGIPFAQPPLGPDRFSAPHPAQPWEGVRDASTAPPMCLQDV--ESMNSSRFV-LNGKQQI 117 CES4A MRW---ILCWS---LTLCLMAQTALGALHTKR-PQVVTKYGTLQGKQMHVG--KTPIQVFLGVPFSRPPLGILRFAPPEPPEPWKGIRDATTYPPGC̈LQES-WGQLASMYVS-TRERYKW 109 CES5A MS---GNWVHPGQILIWAIWVLAAPTKGPSAEGPORNTRLGWIQGKQVTVLGSPVPVNVFLGVPFAAPPLGSLRFTNPOPASPWDNLREATSYPNLCLONS--EWLLLDQHM-LKVHYPK 114

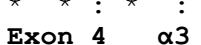

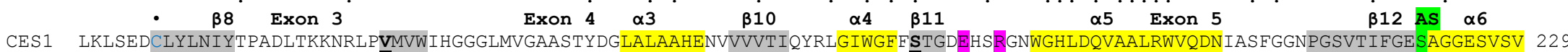

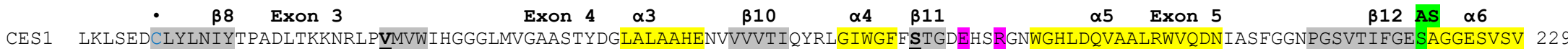

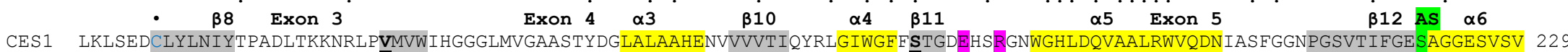

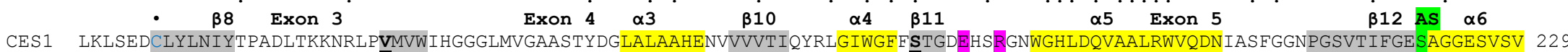
CES2 DSMSEDCLYLSIYTPAHSHEGSNLPVVVWIHGGALVFGMASLYDGSMLAALENVVVVIIQYRLGVLGFF TTGDKHATGNWGYLDQVAALRWVQQNIAHFGGNPDRVTIFGESAGGTSVSS 236 CES3 FSVSEDCLVLNVYSPAEVPAGSGRP $\overline{\mathbf{V}}$ MVWVHGGALITGAATSYDGSALAAYGDVVVVTVQYRLGVLGFF $\overline{\mathbf{S}}$ TGDEHAPGNQGFLDVVAALRWVQENIAPFGGDLNCVTVFGGSAGGS I ISG 237 CES4A LRFSEDCLYLNVYAPARAPGDPQLPVMVWFPGGAFIVGAASSYEGSDLAAREKVVLVFLOHRLGIFGFL CES5A FGVSEDCLYLNIYAPAHADTGSKLPV्V LVWFPGGAFKTGSASIFDGSALAAYEDVLVVVVQYRLGIFGFFTWDQHAPGNWAFKDQVAALSWVQKNIEFFGGDPSSVTIFGESAGAISVSS 234

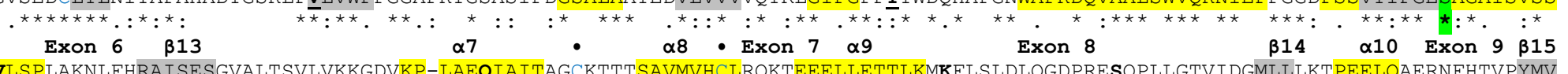
CES1 LVLSPLAKNLFHRAISESGVALTSVLVKKGDVKP-LAEQIAITAGCKTTTSAVMVHCLRQKTEEELLETTLKMKELSLDLQGDPRESQPLLGTVIDGMLLLKTPEELQAERNFHTVPYMV 348 CES2 LVVSPISQGLFHGAIMESGVALLPGLIASSADV--IST $\underline{\mathbf{V} V A N L S A C D Q V D S E A L V G C L R G K S-K E E I L A I N K} \overline{\mathbf{P}}$-------------KMIPGVVDGVFLPRHPQELLASADFQPVPSIV 339 CES3 LVLSPVAAGLFHRAITQSGVITTPGI IDSHPWP--LAQ KIANTLACSSSSPAEMVQCLQQKEGEELVLSKKLKKN-------------TIYPLTVDGTVFPKSPKELLKEKPFHSVPFLM 341 CES4A LMMSPLASGLFHRAISQSGTALFRLFITSNPLK--VAKKVAHLAGCNHNSTQI LVNCLRALSGTKVMRVSNKMRELQLNFQRDPEEIIWSMSPVVDGVVIPDDPLVLLTQGKVSSVPYLI 347

CES5A LI ISPMAKGLFHKAIMESGVAI IPYLEAHDYEKSEDLQVVAHFCGNNASDSEALLRCLRTKPSKELLTLSQKTKSFTR-------------VVDGAFFPNEPLDLLSQKAFKAIPSI I 339

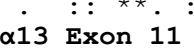
$:: \quad . \quad$ :
Exon 12

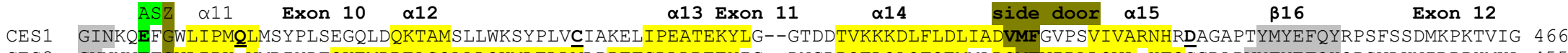
CES2 GVNNNEFGWLIPK-VMRIYDTQKEMDREASQAALQKMLTLLM MPPTFGDLLREEYIG--DNGDPQTLQAQFQEMMADSMFVI PALQVA-HFQ $\bar{C}$ SRAPVYFYEFQHQPSWLKNIRPPHMKA 455 CES3 GVNNHEFSWLIPR-GWGLLDTMEOMSREDMLAISTPVLTSIDVPPEMMPTVIDEYLG--SNSDAQAKCQAFOEFMGDVFINVPTVSFSRYLRDS GSPVFFYEFQHRPSSFAKIKPAWVKA 458

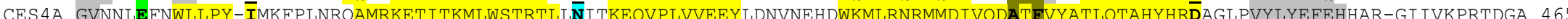
CES5A GVNNHECGT CES5A GVNNHECGFLLPMKEAPEILSGS--NKSLALHLIQN---ILHIPPQYLHLVANEYFH--DKHSLTEIRDSLLDLLGDVFFVVPALITARYHRDAGAPVYFYEFRHRPQCFEDTKPAFVKA 452

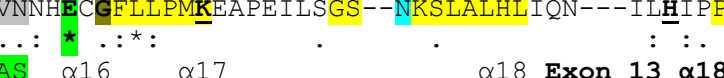

\section{$\therefore{ }^{\star}: \quad \cdot:$}

\section{$\alpha 19$}

te

: *

CES1 DHGDELFSVFGAPFLK--------EGASEEEIRLSKMVMKFWANFARNGNPNGEGLPHWPEYNQKEGYLQIGANTQAAQKLKDKEVAFWTNLFAKKAVE-----KPPQTEHIEL-

作

CES3

CES4A DHGDEMYFLFGGPFAT------GLSMGKEKALSLQMMKYWANFARTGN PNDGNLPCWPRYNKDEKYLQIDFTTRVGMKLKEKKMAFWMSLYQSORPEKQRQF---------------- 561

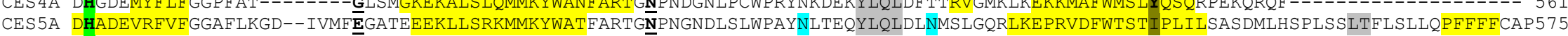

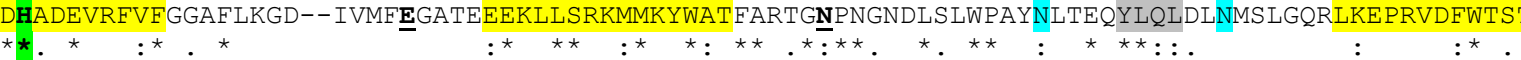


CES1 $34.8 \mathrm{~kb}$ on reverse strand

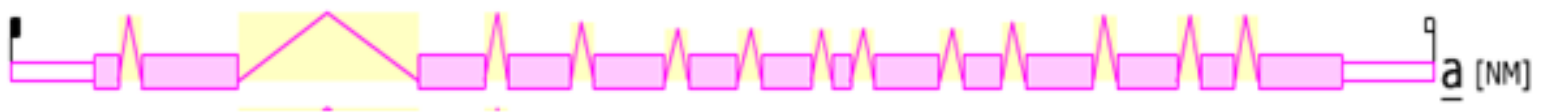

CES2 10.9kb on positive strand

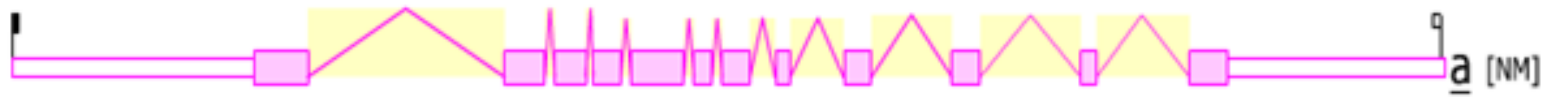

\section{CES3 $13.9 \mathrm{~kb}$ on positive strand}

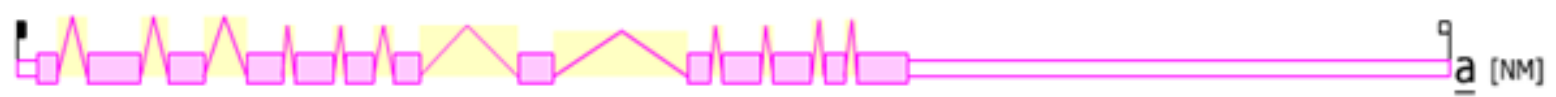

CES4A 22.3kb on positive strand

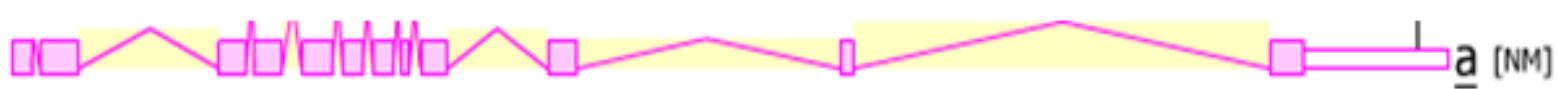

CES5A 79.3kb on reverse strand

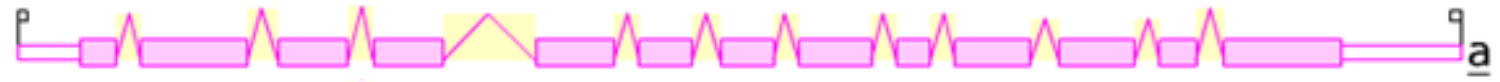


Table 1

Page 25 of 31 


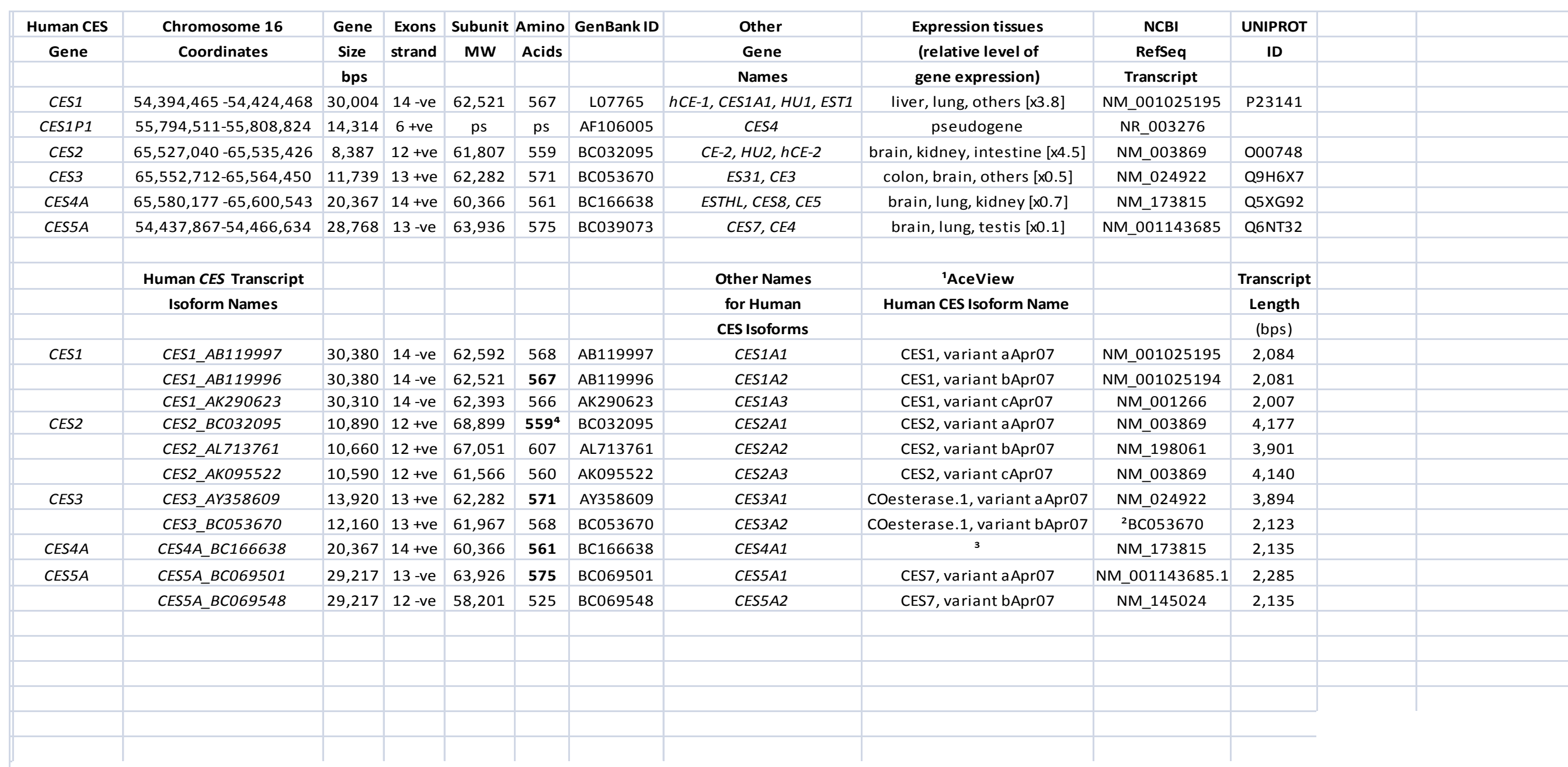


Table 2 


\begin{tabular}{|c|c|c|c|c|c|c|c|c|c|c|c|c|}
\hline Mouse CES & Chromosome 8 & Gene & Exons & Subunit & Amino & GenBank ID & MGIID_YZ & Current MGI & Current & NCBI & Vega ID & EnsembI ID \\
\hline Gene & Coordinates & Size & strand & MW & Acids & & & Symbol_YZ & Gene & Transcript & & \\
\hline (Proposed) & & bps & & & & & & & Symbols & & & \\
\hline Ces1a & $95,544,116-95,572,091$ & 27,979 & $14-v e$ & 61,744 & 563 & BC089371 & MGI:3648919 & Gm4976 & $E G 244595$ & NM_001013764 & none & ENSMUSG00000071047 \\
\hline Ces1b & $95,580,789-95,603,815$ & 23,027 & 13 -ve & 62,197 & 567 & *NM_00108137: & $M G I: 3779470$ & Gm5158 & CesN & NM_001081372 & none & ENSMUSG00000078964 \\
\hline Ces1c & $95,622,914-95,655,182$ & 32,268 & 13 -ve & 61,172 & 554 & BC028907 & MGI:95420 & Es 1 & Es1, Ces-N & NM_007954 & ENSMUSG00000024453 & ENSMUSG00000057400 \\
\hline Ces1d & $95,690,157-95,721,618$ & 31,462 & 14 -ve & 61,788 & 565 & BC019198 & MGI:2148202 & Ces3 & Ces3 & NM_053200 & ENSMUSG00000024539 & ENSMUSG00000056973 \\
\hline Ces1e & $95,725,306-95,753,320$ & 28,015 & 14 -ve & 61,582 & 562 & BC019208 & MGI:95432 & Es22 & Es22 & NM_133660 & ENSMUSG00000024532 & ENSMUSG00000061959 \\
\hline Ces1f & $95,780,331-95,803,599$ & 23,269 & 14 -ve & 61,698 & 561 & BC013479 & MGI:234564 & AU018778 & CesML1, TGH-2 & NM_144930 & ENSMUSG00000024519 & ENSMUSG00000031725 \\
\hline Ces1g & $95,826,807-95,861,053$ & 34,247 & 14 -ve & 62,680 & 565 & BC021150 & MGI:88378 & Ces1 & Ces1 & NM_021456 & ENSMUSG00000024535 & ENSMUSG00000057074 \\
\hline Ces1h & $95,875,926-95,903,624$ & 27,699 & 14 -ve & 62,087 & 562 & AK009689 & MGI:75704 & 2310039D24Rik & AK009689 & XM_134476 & ENSMUSG00000033579 & ENSMUSG00000074156 \\
\hline Ces2a & $107,257,972-107,265,313$ & 37,342 & $12+v e$ & 61,940 & 558 & BC024491 & MGI:2142491 & Ces6 & Ces6 & NM_133960 & OTTMUSG00000027410 & ENSMUSG00000055730 \\
\hline Ces2b & $107,355,572-107,362,353$ & 6,782 & $12+v e$ & 61,927 & 556 & BC015286 & MGI:2448547 & BC015286 & $B C 015286$ & NM_198172 & OTTMUSG00000027467 & ENSMUSG00000050097 \\
\hline $\operatorname{Ces} 2 \mathrm{c}$ & $107,371,033-107,378,161$ & 1 7,129 & $12+v e$ & 62,470 & 561 & BC031170 & MGI:2389505 & Ces2 & Ces2 & NM_145603 & OTTMUSG00000027466 & ENSMUSG00000061825 \\
\hline Ces $2 d-p s$ & $107,391,388-107,397,764$ & 3,762 & $6+v e$ & & & BC034182 & MGI:3704319 & Gm9756 & & XR_002069 & none & ENSMUSG00000031884 \\
\hline Ces2e & $107,450,221-107,457,611$ & 1 7,391 & $12+v e$ & 62,735 & 560 & BC055062 & MGI:2443170 & Ces5 & Ces5 & NM_172759 & none & ENSMUSG00000031886 \\
\hline Ces $2 \mathrm{~h}$ & $107,524,753-107,544,307$ & 719,554 & & & & & MGI:3648740 & Gm5744 & & XM_488149 & none & none \\
\hline Ces3a & $107,572,572-107,582,000$ & 21,512 & $13+v e$ & 61,510 & 554 & AK138932 & MGI:102773 & Es31 & Es31 & NM_198672 & none & ENSMUSG00000069922 \\
\hline Ces3b & $107,607,670-107,617,468$ & 9,799 & $14+v e$ & 63,007 & 568 & BC019047 & Gm4738 & Es31L & Es31L & NM_144511 & none & ENSMUSG00000062181 \\
\hline Ces4a & $107,655,852-107,673,417$ & 17,566 & $14+v e$ & 62,123 & 563 & BC026374 & BC026374 & Ces 8 & Ces8 & NM_146213 & OTTMUSG00000027469 & ENSMUSG00000060560 \\
\hline Ces5a & $96,038,095-96,059,607$ & 21,512 & $13+v e$ & 64,167 & 575 & AB186393 & MGI:1915185 & Ces7 & Ces7 & NM_001003951 & none & ENSMUSG00000058019 \\
\hline & & & & & & & & & & & & \\
\hline & & & & & & & & & & & & \\
\hline & & & & & & & & & & & & \\
\hline & & & & & & & & & & & & \\
\hline & & & & & & & & & & & & \\
\hline & & & & & & & & & & & & \\
\hline & & & & & & & & & & & & \\
\hline & & & & & & & & & & & & \\
\hline & & & & & & & & & & & & \\
\hline & & & & & & & 20 of 21 & & & & & \\
\hline & & & & & & rage & 200131 & & & & & \\
\hline & & & & & & & & & & & & \\
\hline & & & & & & & & & & & & \\
\hline
\end{tabular}


Table 3

Page 29 of 31 


\begin{tabular}{|c|c|c|c|c|c|c|c|c|c|c|c|c|c|}
\hline Rat CES & Chromosomes 19 & Gene & Exons & Subunit & Amino & GenBank & RGD ID & Ortholog & Current & NCBI & Ensembl & UNIPROT & Tissue \\
\hline Gene & (and 1) Coordinates & Size & Strand & MW & Acids & ID & & & gene & Reference & Transcript ID & ID & expressi \\
\hline (Proposed) & & bps & & & & & & & Symbols & Sequence ID & & & [relativ \\
\hline Ces1a & $19: 15,025,350-15,051,534$ & 26,185 & $14+v e$ & 62,362 & 563 & & RGD:1583671 & mouse Gm4976 & LOC679817 & XM_001054575 & ENSRNOT00000060929 & D4AA05 & {$[0.01]$} \\
\hline Ces1c & $19: 14,981,539-15,021,040$ & 39,502 & $14+v e$ & 60,501 & 550 & BC088251 & RGD:2571 & mouse Es1 & Es1 & NM_017004 & ENSRNOTO0000024622 & P10959 & liver $[0$. \\
\hline Ces1d & $19: 14,928,590-14,966,890$ & 38,301 & $14+v e$ & 62,150 & 565 & BC061789 & RGD:70896 & mouse Ces3 & Ces3 & NM_133295 & ENSRNOTO0000021812 & P16303 & liver, lung \\
\hline Ces1e & $19: 14,887,969-14,924,191$ & 36,223 & $14+v e$ & 61,715 & 561 & X81395 & RGD:621508 & mouse Es 22 & Ces1, Es22 & NM_031565 & ENSRNOTO0000020775 & Q924V9 & liver $[0$. \\
\hline Ces1f & $19: 14,849,955-14,876,723$ & 26,769 & $14+v e$ & 62,495 & 561 & BC128711 & RGD:1642419 & none specified & LOC100125372 & NM_001103359 & ENSRNOTO0000024187 & Q64573 & kidney, live \\
\hline Ces $2 a$ & $19: 37,855-44,723$ & 6,869 & 13 -ve & 61,802 & 558 & AY834877 & RGD:708353 & mouse Ces 6 & Ces6 & NM_144743 & ENSRNOTO0000015451 & Q8K3RO & liver [0.C \\
\hline $\operatorname{Ces} 2 \mathrm{c}$ & L:267,887,436-267,894,795 & 7,360 & $12+v e$ & 62,170 & 561 & AB010632 & RGD:621510 & mouse Ces2 & $\operatorname{Ces} 21$ & NM_133586 & ENSRNOTO0000045656 & J70631, 07017 & brain, liver \\
\hline Ces $2 \mathrm{e}$ & $19: 65,698-80,142$ & 14,445 & $12+v e$ & 62,410 & 557 & D50580 & RGD:621563 & mouse Ces 5 & Ces5 & NM_001100477 & ENSRNOTO0000015724 & 035535 & liver $[0 . C$ \\
\hline $\operatorname{Ces} 2 \mathrm{~g}$ & $19: 34,883,500-34,890,289$ & 6,790 & $12+v e$ & 62,909 & 560 & $\mathrm{CH} 473972$ & RGD:1308358 & $\begin{array}{c}\text { mouse } \\
\text { 2210023G05Rik }\end{array}$ & \multicolumn{2}{|l|}{ 2210023G05Rik } & ENSRNOT00000048385 & D3ZXQ0 & kidney, live \\
\hline Ces2h & $19: 34,910,987-34,925,261$ & 14,275 & $12+v e$ & 62,280 & 557 & BC107806 & RGD:1560889 & Gm5744 & Ces2 & NM_001044258 & ENSRNOTO0000019072 & Q32Q55 & intestine [ \\
\hline Ces $2 i$ & $L: 267,807,848-267,815,235$ & 7,388 & $11+v e$ & 62,072 & 559 & XM212849 & RGD:1565045 & Mouse Ces2 & $R G D 1565045$ & XM_001074128 & ENSRNOTO0000015997 & D3ZE31 & not availe \\
\hline Ces $2 \mathrm{j}$ & $19: 215,376-222,512$ & 7,137 & $12+v e$ & 61,795 & 556 & & RGD:1591368 & Mouse Ces2 & LOC685645 & XM_001074128 & ENSRNOT00000061734 & D3ZP14 & {$[0.01]$} \\
\hline Ces3a & $19: 34,929,247-34,937,264$ & 8,018 & $14+v e$ & 62,393 & 563 & & RGD:1588734 & Human CES3 & & & ENSRNOT00000040499 & & not availe \\
\hline Ces4a & $19: 34,948,579-34,965,647$ & 17,069 & $14+v e$ & 63,446 & 563 & & RGD:1307418 & mouse Ces8 & Ces8 & NM_001106176 & ENSRNOTO0000019169 & D4AE76 & {$[0.01]$} \\
\hline Ces5a & $19: 11,910,831-11,938,412$ & 27,582 & $11+v e$ & 64,401 & 575 & AF479659 & RGD:1549717 & mouse Ces7 & Ces7 & NM_001012056 & ENSRNOTO0000049452 & Q5GRG2 & {$[0.01]$} \\
\hline & & & & & & & & & & & & & \\
\hline & & & & & & & & & & & & & \\
\hline & & & & & & & & & & & & & \\
\hline & & & & & & & & & & & & & \\
\hline & & & & & & & & & & & & & \\
\hline & & & & & & & & & & & & & \\
\hline & & & & & & & & & & & & & \\
\hline & & & & & & & & & & & & & \\
\hline & & & & & & & & & & & & & \\
\hline & & & & & & & & & & & & & \\
\hline & & & & & & & & & & & & & \\
\hline & & & & & & & & & & & & & \\
\hline & & & & & & & & & & & & & \\
\hline & & & & & & & & & & & & & \\
\hline & & & & & & & age $30 \hat{~ o f ~} 31$ & & & & & & \\
\hline & & & & & & & & & & & & & \\
\hline & & & & & & & & & & & & & \\
\hline
\end{tabular}




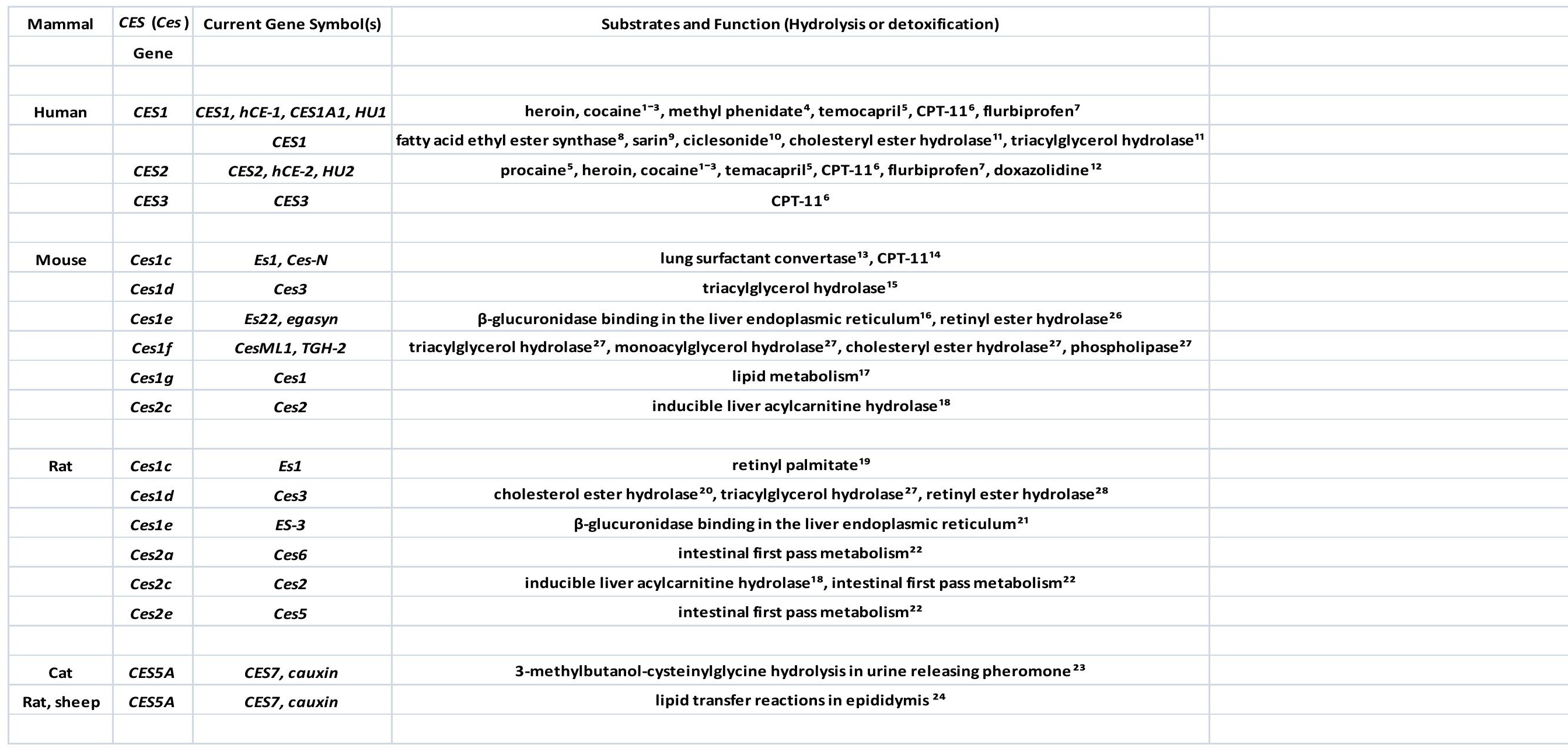

